\title{
Metabolic acidosis and the progression of chronic kidney disease
}

Wei Chen ${ }^{1}$ and Matthew K Abramowitz ${ }^{1,2^{*}}$

\begin{abstract}
Metabolic acidosis is a common complication of chronic kidney disease. Accumulating evidence identifies acidosis not only as a consequence of, but as a contributor to, kidney disease progression. Several mechanistic pathways have been identified in this regard. The dietary acid load, even in the absence of overt acidosis, may have deleterious effects. Several small trials now suggest that the treatment of acidosis with oral alkali can slow the progression of kidney disease.
\end{abstract}

Keywords: Bicarbonate, Dietary acid, Net endogenous acid production, Sodium bicarbonate, Alkali, Ammonia, Complement, Endothelin, Aldosterone

\section{Review}

Metabolic acidosis is a common complication of chronic kidney disease (CKD). Based on a cross-sectional analysis of the National Health and Nutrition Examination Survey, an estimated 26 million adults in the United States have CKD, and approximately 700,000 individuals have an estimated glomerular filtration rate (eGFR) less than $30 \mathrm{~mL} /$ $\mathrm{min} / 1.73 \mathrm{~m}^{2}$ [1]. As $30-50 \%$ of those with eGFR $<30 \mathrm{~mL} /$ $\min / 1.73 \mathrm{~m}^{2}$ have metabolic acidosis [2-4], approximately 200,000 to 350,000 individuals with CKD stage 4 and 5 have chronic metabolic acidosis in the United States.

Chronic metabolic acidosis may have various adverse effects in patients with CKD, including altered skeletal metabolism [5], insulin resistance [6], protein-energy wasting [7-9], and accelerated progression of kidney disease. In epidemiologic studies, low serum bicarbonate levels have been associated with high mortality (Table 1 ). In a study of 1,240 male patients with non-dialysis dependent CKD, the lowest mortality was observed among those with baseline serum bicarbonate levels of $26-29 \mathrm{mEq} / \mathrm{L}$, whereas patients with levels $<22 \mathrm{mEq} / \mathrm{L}$ had a $43 \%$ higher risk of mortality [10]. Using data from the African American Study of Kidney Disease and Hypertension (AASK) trial, Raphael et al. showed that higher bicarbonate levels within the range of 20 to $30 \mathrm{mEq} / \mathrm{L}$ were associated with reduced risk of the

\footnotetext{
* Correspondence: matthew.abramowitz@einstein.yu.edu

'Division of Nephrology, Department of Medicine, Albert Einstein College of Medicine, Bronx, NY, USA

${ }^{2}$ Department of Epidemiology \& Population Health, Albert Einstein College of Medicine, 1300 Morris Park Avenue, Ullmann 615, Bronx, NY 10461, USA
}

clinical composite outcome of death, dialysis or worsening renal function [11]. This review focuses specifically on the effect of metabolic acidosis on the progression of kidney disease.

\section{Pathophysiology leading to acidosis in CKD}

Under normal conditions, the extracellular $\mathrm{H}^{+}$concentration is tightly regulated and varies little from the normal value of approximately $40 \mathrm{nanomol} / \mathrm{L}$. Regulation of acidbase homeostasis involves three basic steps: chemical buffering by extracellular and intracellular buffers, alteration of alveolar ventilation, and changes in renal $\mathrm{H}^{+}$excretion [17]. The kidneys regulate $\mathrm{H}^{+}$excretion by reabsorbing filtered $\mathrm{HCO}_{3}{ }^{-}$and generating new $\mathrm{HCO}_{3}{ }^{-}$in response to various stimuli. Secreted $\mathrm{H}^{+}$combine with urinary buffers such as $\mathrm{HPO}_{4}{ }^{2-}$ and ammonia. In CKD the reduction in functioning nephrons causes defects in renal excretion of acid, mainly in the form of ammonium [18]. A fraction of patients may have inappropriate bicarbonate wasting in the urine [19].

The acidosis in CKD usually remains relatively stable. In uncomplicated acidosis, the serum bicarbonate levels typically are $>12 \mathrm{mEq} / \mathrm{L}$ and blood $\mathrm{pH}$ is $>7.2[19,20]$. There are two general possibilities for this stabilization of serum bicarbonate levels. One is that after an initial period of acid retention, the excretion and production of acid equalize. The other possibility is that acidosis evokes extrarenal mechanisms that dispose of the endogenous acid not excreted in the urine. The major source of such 
Table 1 Observational studies of serum bicarbonate and long-term outcomes in persons without end-stage renal disease

\begin{tabular}{|c|c|c|c|c|c|c|}
\hline Study & Population & Main outcome(s) & Findings & $\begin{array}{l}\mathrm{pH} \text { or } \mathrm{pCO}_{2} \\
\text { available }\end{array}$ & Strengths & Limitations \\
\hline \multirow[t]{2}{*}{$\begin{array}{l}\text { Shah et al. } \\
2009[4]\end{array}$} & \multirow{2}{*}{$\begin{array}{l}\text { 5,422 outpatients in } \\
\text { the Bronx, NY; } 9 \% \\
\text { with } \mathrm{eGFR}<60 \\
\mathrm{~mL} / \mathrm{min} / 1.73 \mathrm{~m}^{2}\end{array}$} & \multirow{2}{*}{$\begin{array}{l}\text { Kidney disease progression, defined } \\
\text { as } 50 \% \text { decrease in eGFR or } \\
\text { eGFR }<15 \mathrm{~mL} / \mathrm{min} / 1.73 \mathrm{~m}^{2}\end{array}$} & \multirow{2}{*}{$\begin{array}{l}\text { HR } 1.54(95 \% \mathrm{Cl} 1.13-2.09) \text { for progression, } \\
\text { for serum bicarbonate } \leq 22 \mathrm{mEq} / \mathrm{L} \text { compared } \\
\text { with } 25-26 \mathrm{mEq} / \mathrm{L}\end{array}$} & \multirow[t]{2}{*}{ No } & \multirow[t]{2}{*}{$\begin{array}{l}\text { - Ethnically } \\
\text { diverse cohort }\end{array}$} & $\begin{array}{l}\text { - Single measure } \\
\text { of serum bicarbonate }\end{array}$ \\
\hline & & & & & & $\begin{array}{l}\text { - Data derived from } \\
\text { clinical and } \\
\text { administrative dataset }\end{array}$ \\
\hline \multirow[t]{2}{*}{$\begin{array}{l}\text { Menon et al. } \\
2010[12]\end{array}$} & \multirow{2}{*}{$\begin{array}{l}1,781 \text { participants } \\
\text { (839 randomized, } 942 \\
\text { non-randomized) } \\
\text { from the MDRD study }\end{array}$} & \multirow{2}{*}{$\begin{array}{l}\text { (1) ESRD (need for dialysis or } \\
\text { transplantation); (2) all-cause mortality; } \\
\text { (3) composite of } 1 \text { and } 2\end{array}$} & \multirow{2}{*}{$\begin{array}{l}\text { HR } 1.05 \text { (0.87-1.28), } 0.99 \text { (0.75-1.13), } 1.04 \\
\text { (0.87-1.24) for need for kidney failure, } \\
\text { all-cause mortality, and composite outcome, } \\
\text { respectively, for serum bicarbonate } 11-20 \\
\text { compared with } 26-40 \mathrm{mEq} / \mathrm{L}\end{array}$} & \multirow[t]{2}{*}{ No } & $\begin{array}{l}\text { - Well-characterized } \\
\text { cohort }\end{array}$ & \multirow[t]{2}{*}{$\begin{array}{l}\text { - Single measure of } \\
\text { serum bicarbonate }\end{array}$} \\
\hline & & & & & $\begin{array}{l}\text { - Adjustment for } \\
\text { measured GFR }\end{array}$ & \\
\hline \multirow[t]{3}{*}{$\begin{array}{l}\text { Raphael et al. } \\
2011 \text { [11] }\end{array}$} & \multirow[t]{3}{*}{$\begin{array}{l}1,090 \text { participants of } \\
\text { the AASK trial }\end{array}$} & \multirow{3}{*}{$\begin{array}{l}\text { Composite outcome of death, ESRD } \\
\text { (dialysis or transplantation), or GFR } \\
\text { event (defined as a GFR reduction by } \\
50 \% \text { or by } 25 \mathrm{ml} / \mathrm{min} / 1.73 \mathrm{~m}^{2} \text { from } \\
\text { baseline) }\end{array}$} & \multirow{3}{*}{$\begin{array}{l}\text { HR } 0.960 \text { (0.924-0.998) for composite } \\
\text { outcome, per mEq/L higher baseline } \\
\text { serum bicarbonate }\end{array}$} & \multirow[t]{3}{*}{ No } & $\begin{array}{l}\text { - Well-characterized } \\
\text { cohort }\end{array}$ & \multirow[t]{3}{*}{$\begin{array}{l}\text { - Single measure of } \\
\text { serum bicarbonate }\end{array}$} \\
\hline & & & & & $\begin{array}{l}\text { - Adjustment for } \\
\text { measured GFR }\end{array}$ & \\
\hline & & & & & $\begin{array}{l}\text { - Adjustment for } \\
\text { errors in measurement } \\
\text { of GFR and proteinuria }\end{array}$ & \\
\hline $\begin{array}{l}\text { Kovesdy et al. } \\
2009[10]\end{array}$ & $\begin{array}{l}1,240 \text { adults at a } \\
\text { Veterans Affairs } \\
\text { Medical Center; } 87 \% \\
\text { with CKD stages } 3 \\
\text { and } 4\end{array}$ & $\begin{array}{l}\text { (1) All-cause mortality; (2) composite } \\
\text { of predialysis mortality and initiation of } \\
\text { dialysis }\end{array}$ & $\begin{array}{l}\text { U-shaped association; HR for mortality } 1.43 \\
(1.10-1.87) \text { for serum bicarbonate }<22 \\
\text { compared with } 26-29 \mathrm{mEg} / \mathrm{L} \text {; similar results for } \\
\text { composite outcome }\end{array}$ & No & $\begin{array}{l}\text { - Adjustment for } \\
\text { time-varying serum } \\
\text { bicarbonate levels }\end{array}$ & $\begin{array}{l}\text { - Data derived from } \\
\text { clinical and administrative } \\
\text { dataset }\end{array}$ \\
\hline \multirow[t]{2}{*}{$\begin{array}{l}\text { Navaneethan } \\
\text { et al. } 2011 \text { [13] }\end{array}$} & \multirow{2}{*}{$\begin{array}{l}41,749 \text { outpatients } \\
\text { with } \mathrm{eGFR}<60 \\
\mathrm{~mL} / \mathrm{min} / 1.73 \mathrm{~m}^{2} \\
\text { in Cleveland, } \mathrm{OH}\end{array}$} & \multirow[t]{2}{*}{ All-cause mortality } & \multirow{2}{*}{$\begin{array}{l}\text { U-shaped association; HR } 1.23 \text { (1.16-1.31) } \\
\text { for bicarbonate <23 compared with } \\
23-32 \mathrm{mEq} / \mathrm{L} ; \mathrm{HR} 1.59(1.49-1.69) \text { for } \\
\text { reaching bicarbonate }<23 \mathrm{mEq} / \mathrm{L}\end{array}$} & \multirow[t]{2}{*}{ No } & $\begin{array}{l}\text { - Examination of } \\
\text { temporal change in } \\
\text { serum bicarbonate }\end{array}$ & \multirow[t]{2}{*}{$\begin{array}{l}\text { - Data derived from } \\
\text { clinical and administrative } \\
\text { dataset }\end{array}$} \\
\hline & & & & & - Large sample size & \\
\hline $\begin{array}{l}\text { Dobre et al. } \\
2013[14]\end{array}$ & $\begin{array}{l}3,939 \text { participants } \\
\text { from the CRIC study }\end{array}$ & $\begin{array}{l}\text { (1) Renal outcome, defined as } 50 \% \\
\text { decrease in eGFR or ESRD (dialysis or } \\
\text { transplantation); (2) atherosclerotic events; } \\
\text { (3) CHF events; } \\
\text { (4) all-cause mortality }\end{array}$ & $\begin{array}{l}\text { Per mEq/L higher serum bicarbonate, HR } 0.97 \\
(0.94-0.99) \text { for renal outcome; } 0.99(0.95-1.03) \\
\text { for atherosclerotic event; } 1.14(1.03-1.26) \text { for } \\
\text { CHF for serum bicarbonate } \geq 24 \mathrm{mEq} / \mathrm{L} ; 0.98 \\
(0.95-1.02) \text { for mortality }\end{array}$ & No & $\begin{array}{l}\text { - Well-characterized } \\
\text { cohort }\end{array}$ & $\begin{array}{l}\text { - Single measure of serum } \\
\text { bicarbonate }\end{array}$ \\
\hline \multirow[t]{2}{*}{$\begin{array}{l}\text { Kanda et al. } \\
2013[15]\end{array}$} & \multirow{2}{*}{$\begin{array}{l}113 \text { Japanese } \\
\text { patients } \geq 60 \text { years } \\
\text { old with eGFR< } \\
60 \mathrm{~mL} / \mathrm{min} / 1.73 \mathrm{~m}^{2}\end{array}$} & \multirow{2}{*}{$\begin{array}{l}\text { Kidney disease progression, defined } \\
\text { as } 25 \% \text { decrease in eGFR or initiation } \\
\text { of dialysis }\end{array}$} & \multirow[t]{2}{*}{$\begin{array}{l}\text { HR } 0.791 \text { (0.684-0.914) for progression, } \\
\text { per mEq/L higher serum bicarbonate }\end{array}$} & \multirow[t]{2}{*}{ No } & \multirow[t]{2}{*}{$\begin{array}{l}\text { - Focus on elderly } \\
\text { cohort }\end{array}$} & $\begin{array}{l}\text { - Single measure of serum } \\
\text { bicarbonate }\end{array}$ \\
\hline & & & & & & - Small sample size \\
\hline \multirow[t]{2}{*}{$\begin{array}{l}\text { Raphael et al. } \\
2013 \text { [16] }\end{array}$} & \multirow[t]{2}{*}{$\begin{array}{l}15,836 \text { participants } \\
\text { of NHANES III }\end{array}$} & \multirow[t]{2}{*}{ All-cause mortality } & \multirow{2}{*}{$\begin{array}{l}\text { HR } 1.75(1.12-2.74), 1.56 \text { (0.78-3.09), and } \\
2.56(1.49-4.38) \text { for total population, non-CKD, } \\
\text { and CKD subgroups, respectively, for serum } \\
\text { bicarbonate }<22 \mathrm{mEq} / \mathrm{L} \text { compared with } \\
26-30 \mathrm{mEq} / \mathrm{L}\end{array}$} & \multirow[t]{2}{*}{ No } & $\begin{array}{l}\text { - Nationally representative } \\
\text { cohort }\end{array}$ & \multirow[t]{2}{*}{$\begin{array}{l}\text { - Single measure of serum } \\
\text { bicarbonate }\end{array}$} \\
\hline & & & & & $\begin{array}{l}\text { - Compared CKD and } \\
\text { non-CKD subgroups }\end{array}$ & \\
\hline
\end{tabular}

renal disease; CKD, chronic kidney disease; CRIC, Chronic Renal Insufficiency Cohort; CHF, congestive heart failure; NHANES, National Health and Nutrition Examination Survey. 
buffering would be base derived from bone. Carefully conducted balance studies in CKD patients with acidosis found a positive acid balance of approximately 10$20 \mathrm{mEq}$ per day and negative calcium balance that improved with correction of acidosis [21,22]. However, the degree of acid retention has been debated, with the suggestion that these findings resulted from systematic measurement error [23]. While the magnitude of acid retention may be less than reported, it seems likely that acid production does exceed excretion in the setting of chronic renal acidosis [24].

The acidosis in mild to moderate CKD is predominantly hyperchloremic, with an increased anion gap observed variably and generally only with advanced CKD [25-27]. However, accounting for changes in serum albumin and other electrolytes in the anion gap calculation reveals a slightly more nuanced view. This maneuver reveals minor elevations in the anion gap, which are associated with decrements in serum bicarbonate, even in the CKD stage 2 eGFR range [28]. Although small, these differences in anion gap are independently associated with mortality [28]. Thus, there may be low-level accumulation of organic solutes even when the GFR is relatively preserved that partially accounts for changes in the serum bicarbonate level.

\section{Metabolic acidosis and progression of kidney disease}

Epidemiologic studies have demonstrated that lower serum bicarbonate is associated with an increased risk of kidney disease progression (Table 1). In a single center retrospective cohort study involving patients with and without kidney disease, the risk of CKD progression was 54\% (95\% confidence interval (CI) 13-109\%) higher for patients with bicarbonate levels $<22 \mathrm{mEq} / \mathrm{L}$ compared with bicarbonate levels of 25 to $26 \mathrm{mEq} / \mathrm{L}$ [4]. Among 1,781 participants with CKD stages 2-4 from the Modification of Diet in Renal Disease Study, compared with serum bicarbonate levels $\geq 26 \mathrm{mEq} /$ $\mathrm{L}$, levels $\leq 20 \mathrm{mEq} / \mathrm{L}$ were associated with a higher risk of kidney failure (hazard ratio (HR) 2.22 (95\% CI, 1.83-2.68)) while adjusting for demographic and cardiovascular disease factors, serum albumin, proteinuria, and cause of kidney disease [12]. However, the association was substantially attenuated and non-significant after adjustment for GFR, measured using iothalamate clearance (HR 1.05 (95\% CI, 0.87-1.28)). The implication was that lower serum bicarbonate was a marker for more advanced kidney disease, and that analyses adjusting for estimated GFR were limited by residual confounding. However, Raphael et al. performed a similar analysis using data from 1,094 African American participants of the AASK trial with GFR measured by iothalamate clearance [11]. After controlling for measured GFR, higher serum bicarbonate in the 20 to $30 \mathrm{mEq} / \mathrm{L}$ range was associated with a lower risk of dialysis or worsening kidney function (HR 0.932 (95\% CI,
0.881-0.986) per $1 \mathrm{mEq} / \mathrm{L}$ serum bicarbonate). Most recently, in 3,939 participants with CKD stages 2-4 in the Chronic Renal Insufficiency Cohort, every $1 \mathrm{mEq} / \mathrm{L}$ higher serum bicarbonate level was associated with a $3 \%$ (95\% CI, 1-6\%) lower risk of developing end-stage renal disease or a 50\% decline in eGFR during follow-up [14].

Several factors have been implicated in the effect of metabolic acidosis on the progression of kidney disease. These include ammonia-induced complement activation and increased production of endothelin and aldosterone (Figure 1). Although total ammonium excretion decreases with progressive CKD, ammonia generation per nephron actually increases [29]. This adaptive response may be deleterious for the surviving nephrons [30]. Nath et al. examined the role of ammonia in the pathogenesis of tubulointerstitial injury using the rat remnant kidney model [31]. Chronic sodium bicarbonate supplementation lowered renal vein total ammonia concentrations, reduced tubular deposition of complement components $\mathrm{C} 3$ and C5b-9, and ameliorated structural and functional evidence of tubulointerstitial damage. The authors proposed that ammonia, as a nitrogen nucleophile, reacted biochemically with C3 to trigger the alternative complement pathway. Therefore, the compensatory increase in single-nephron ammoniagenesis observed in CKD could further instigate progressive kidney injury.

Acidosis has been shown to increase endothelin (ET)mediated tubulo-interstitial injury as well. ET is an endothelial cell-derived peptide with 3 mammalian isoforms: ET-1, ET-2, and ET-3. The kidneys produce ET-1 in relatively high amounts and contain abundant ET receptors, particularly in the vasculature and the medulla [32]. In vitro evidence has demonstrated that ET-1 promotes the synthesis of fibronectin and collagen [33]. Several in vivo studies have correlated renal ET-1 gene expression and urinary excretion with the degree of proteinuria and glomerular and tubulo-interstitial damage [34]. ET regulates multiple renal functional parameters, one of which is acid-base handling. Specifically, ET-1 mediates increased renal acid excretion in response to a systemic acid challenge. Rats given a dietary acid load as $\left(\mathrm{NH}_{4}\right)_{2} \mathrm{SO}_{4}$ increased ET-1 addition to renal interstitial fluid, and pharmacological inhibition of ET receptors using bosentan blunted distal tubule acidification [35]. Using a remnant kidney model, Wesson and colleagues demonstrated that dietary protein-induced tubulo-interstitial injury and GFR decline were mediated by ET, and that alkali supplementation prevented these effects $[36,37]$.

Excess aldosterone could also mediate the decline in GFR caused by acidosis, via its hemodynamic effects and its pro-fibrotic actions [38]. Hyperaldosteronism in the setting of reduced nephron mass contributes to hypertension, proteinuria and glomerulosclerosis in the remnant 


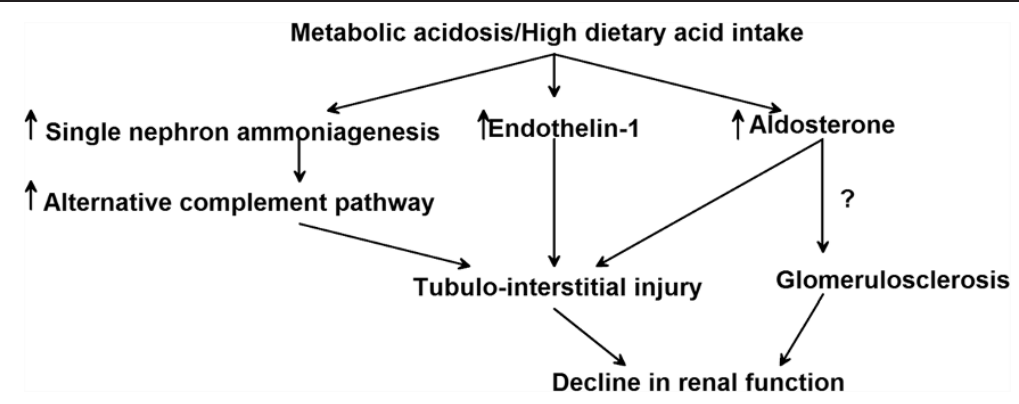

Figure 1 Pathogenesis of kidney disease progression due to chronic metabolic acidosis. Metabolic acidosis and/or a high dietary acid load may contribute to progressive kidney disease through multiple mechanisms, including increased ammonia generation per nephron leading to activation of the alternative complement pathway and increased endothelin-1 and aldosterone levels in the kidney. Each of these factors may cause tubule-interstitial injury leading to a decline in kidney function. Hyperaldosteronism could also accelerate glomerulosclerosis, although glomerular injury due to metabolic acidosis has not been reported in animal models.

kidney model $[39,40]$. Chronic aldosterone treatment plus a high salt diet produced hypertension and severe glomerular and tubulo-interstitial injury in non-nephrectomized rats [41,42]. Schambelan et al. examined the effect of chronic metabolic acidosis on adrenocortical hormone production by administering $\mathrm{NH}_{4} \mathrm{Cl}$ for 5 days to four normal subjects, and found that chronic metabolic acidosis induced a sustained stimulation of aldosterone secretion [43]. Aldosterone mediates increased distal nephron acidification in the setting of metabolic acidosis, and prevention of kidney disease with alkali in the rat remnant kidney model was associated with reduced aldosterone production in kidney cortex $[44,45]$.

More recently, the effect of acidosis on kidney injury has been explored using gene expression analyses. Raj et al. examined the effect of exposure of Madin-Darby canine kidney cells (an immortalized cell line derived from the dog distal renal tubule) to medium with $\mathrm{pH} 7.4$ and 7.0 for 24 hours, and found that acid stress upregulated the expression of genes that might participate in the pro-inflammatory process leading to glomerulosclerosis and fibrosis [46].

\section{Dietary acid, acid retention and progression of kidney disease}

The net dietary acid load is determined by the balance of acid-forming and base-forming precursors in the diet. Common foods that provide a high dietary acid load include cheese, meat, eggs and grains, whereas fruits and vegetables are rich in alkali precursors $[47,48]$. Generally speaking, diets high in animal protein produce high levels of net endogenous acid production (NEAP), whereas vegan and vegetarian diets result in low, or even negative, NEAP. Low NEAP can be achieved even while preserving the proportion of energy derived from dietary protein. This was demonstrated in the Dietary Approaches to Stop Hypertension (DASH) trial, where a diet incorporating increased fruit and vegetable intake produced substantially lower NEAP than the typical American diet [47].

The usual diet consumed in the Western world is quite different from that which our ancestors ate. Ancestral human diets were largely plant-based, and were characterized by much lower levels of refined carbohydrates and sodium, and much higher levels of fiber and potassium, than contemporary diets [49,50]. Sebastian et al. estimated the net acid load from retrojected ancestral pre-agricultural diets and compared it with contemporary diets [51]. They found that $87 \%$ of 159 retrojected pre-agricultural diets were net base-producing with a mean NEAP of $-88 \mathrm{mEq}$ per day, compared with $+48 \mathrm{mEq}$ per day for the average American diet. Similarly, Strohle et al. examined the dietary net acid load for 229 worldwide historically-studied huntergatherer societies, and confirmed that the NEAP became progressively more positive as the dietary plantto-animal ratio declined [52]. The historical shift from negative to positive NEAP, or from net base-producing to acid-producing, is thought due to the displacement of high-bicarbonate-yielding plant foods in the ancestral diet by cereal grains and energy-dense, nutritionpoor foods in the contemporary diet. It has been postulated that on an evolutionary scale this change has occurred rapidly, in a time span too brief for adequate genetic adaptation [53-55]. The resultant mismatch between the modern Western diet and a core metabolic machinery that was selected for 50,000 to 100,000 years ago may therefore contribute to chronic disease [56].

The high dietary acid load of contemporary diets could impair kidney function by inducing metabolic acidosis or even subclinical acid retention. In rats, acid loading increased blood and renal cortical acid content measured by microdialysis, consistent with net acid retention [57]. Despite no difference in blood pH or serum bicarbonate, rats with reduced nephron mass had higher 
tissue acid content compared with control animals. Dietary acid accelerated GFR decline, which was ameliorated by dietary alkali [58]. The decline in GFR caused by dietary acid could be mediated by increased kidney ET and aldosterone production [45,59] (Figure 1).

In humans, higher NEAP has been associated with lower serum bicarbonate in persons with kidney disease and in the general population [60,61]. Furthermore, this association is strongest among those with more advanced CKD and among middle-aged and older individuals, populations in whom the capacity to excrete an acid load is relatively impaired [60,61]. Among 632 participants from the AASK cohort study, higher NEAP was associated with a faster decline in GFR over a median follow up of 3.2 years [62]. Thus, animal studies and epidemiologic data link dietary acid load with the pathogenesis of progressive CKD.

\section{Treatment}

Several single-center clinical studies have examined the effect of alkali therapy on the progression of kidney disease. In a 2-year, open-label, randomized trial, 134 patients with CKD stage 4 and serum bicarbonate levels of 16 to $20 \mathrm{mEq} / \mathrm{L}$ were assigned to receive oral sodium bicarbonate or to continue routine care [63]. Sodium bicarbonate was provided as $600 \mathrm{mg}$ tablets dosed thrice daily and increased as necessary to maintain bicarbonate levels $\geq 23 \mathrm{mEq} / \mathrm{L}$. Compared with the control group, bicarbonate-supplemented patients experienced a slower decline in creatinine clearance (5.93 vs. $1.88 \mathrm{~mL} / \mathrm{min} /$ $\left.1.73 \mathrm{~m}^{2} ; \mathrm{p}<0.0001\right)$ and fewer developed ESRD. This was followed by another prospective interventional study of 59 patients with a clinical diagnosis of hypertensive nephropathy, all treated with regimens including an angiotensin-converting enzyme (ACE) inhibitor, who had an eGFR $20-59 \mathrm{~mL} / \mathrm{min} / 1.73 \mathrm{~m}^{2}$ and a serum bicarbonate $<22 \mathrm{mEq} / \mathrm{L}$ [64]. Thirty patients prescribed sodium citrate were compared with the remaining 29 patients who were unable or unwilling to take sodium citrate or bicarbonate. After 24 months, patients taking sodium citrate had lesser eGFR decline and significantly lower urinary ET-1 excretion and tubulo-interstitial injury, as measured by urinary $\mathrm{N}$-acetyl- $\beta$ - $\mathrm{D}$-glucosaminidase (NAG). In a second study by the same group, 120 patients with hypertensive nephropathy and CKD stage 2 , all taking ACE inhibitors, were randomized in a blinded fashion to receive $0.5 \mathrm{mEq} / \mathrm{kg} /$ day sodium bicarbonate, sodium chloride, or matching placebo. After 5 years, the rate of eGFR decline was slowest in the patients randomized to sodium bicarbonate, and they had lower urine ET-1 and NAG compared with the other groups [65]. Of note, the mean serum bicarbonate at study entry among these 120 participants was $26.2 \mathrm{mEq} /$ $\mathrm{L}$, well within the normal range.
More recently, dietary modification has been examined by Goraya and colleagues $[66,67]$. In patients with CKD stage 2 due to hypertensive nephropathy, 30 days of increased fruit and vegetable consumption produced similar reductions in urinary NAG and albuminuria as did oral sodium bicarbonate [66]. Similar results were found in 71 patients with stage 4 CKD and serum bicarbonate $<22 \mathrm{mEq} / \mathrm{L}$ who were randomized to 1 year of sodium bicarbonate at $1.0 \mathrm{mEq} / \mathrm{kg}$ per day or increased fruits and vegetables to reduce dietary acid by half [67]. The serum bicarbonate increased with the dietary intervention, although less than in the bicarbonate group, whose alkali dose would be expected to nearly completely neutralize the dietary acid load. The aforementioned markers of kidney injury declined similarly in the 2 groups. It is encouraging that there were no complications from hyperkalemia, but it should be noted that only patients with plasma $\mathrm{K}^{+} \leq 4.6 \mathrm{mEq} / \mathrm{L}$ were enrolled in the study.

Thus, accumulating evidence suggests that treatment of chronic metabolic acidosis could slow the progression of CKD. However, the evidence base is not yet definitive. A systemic review was performed examining the published literature regarding alkali therapy through July 2011 [68]. The authors concluded that although oral alkali might afford a long-term benefit in slowing the progression of CKD, differences in study protocols and small sample sizes precluded definitive conclusions. Additional, more nuanced questions also remain unanswered. If alkali therapy does retard progression, what serum bicarbonate level should be targeted? Is there a risk to overcorrection of acidosis? Higher serum bicarbonate was associated with increased risk of congestive heart failure in the CRIC study [14], but to date interventional studies have not demonstrated significant metabolic alkalosis or fluid overload with even high-dose alkali. Is serum bicarbonate even the right target, given evidence of acid retention and deleterious effects within the normal range of serum bicarbonate? To what extent should dietary interventions to reduce the dietary acid load be employed in lieu of, or in addition to, oral alkali? There are 3 ongoing randomized controlled trials of alkali therapy in patients with CKD that have the potential to answer some of these questions and to impact clinical practice (NCT01640119 [69]; NCT01452412 [70]; EUDRACT Number 2012-001824-36 [71]). A summary of these trials is provided in Table 2. Several smaller studies are examining other effects of base, including changes in urinary TGF- $\beta 1$ (NCT01574157), vascular endothelial function (NCT02031770), and its role in sickle cell disease (NCT01894594).

\section{Conclusion}

Patients with CKD develop metabolic acidosis due to reduced kidney mass and defects in renal acid excretion. 
Table 2 Summary of on-going randomized clinical trials of alkali therapy in patients with chronic kidney disease

\begin{tabular}{|c|c|c|c|}
\hline Title & $\begin{array}{l}\text { Correction of Metabolic Acidosis } \\
\text { with Use of Bicarbonate in } \\
\text { Chronic Renal Insufficiency } \\
\text { (NCT01640119) [69] }\end{array}$ & $\begin{array}{l}\text { Alkali Therapy in Chronic Kidney } \\
\text { Disease (NCT01452412) [70] }\end{array}$ & $\begin{array}{l}\text { Oral Sodium Bicarbonate Supplementation } \\
\text { in Patients with Chronic Metabolic Acidosis } \\
\text { and Chronic Kidney Disease (EUDRACT } \\
\text { Number 2012-001824-36) [71] }\end{array}$ \\
\hline $\begin{array}{l}\text { Estimated primary } \\
\text { completion date }\end{array}$ & $12 / 2013$ & $1 / 2015$ & Not available ${ }^{\#}$ \\
\hline $\begin{array}{l}\text { Anticipated } \\
\text { sample size }\end{array}$ & 728 & 150 & 200 \\
\hline CKD stage & Stage $3 b \& 4$ & Stage $3 \& 4$ & Stage $3 \& 4$ \\
\hline $\begin{array}{l}\text { Serum bicarbonate } \\
\text { levels at randomization }\end{array}$ & $\geq 18 \mathrm{mEq} / \mathrm{L}$ & $20-26 \mathrm{mEq} / \mathrm{L}$ & $<21 \mathrm{mEq} / \mathrm{L}$ \\
\hline Study design & Randomized, open label & $\begin{array}{l}\text { Randomized, placebo-controlled, } \\
\text { double blind }\end{array}$ & Randomized, open label \\
\hline Intervention & $\begin{array}{l}\text { Bicarbonate administration to } \\
\text { keep bicarbonate levels between } \\
24-28 \mathrm{mEq} / \mathrm{L}\end{array}$ & $\begin{array}{l}\text { Sodium bicarbonate } 0.4 \mathrm{mEq} / \mathrm{kg} \\
\text { ideal body weight per day }\end{array}$ & $\begin{array}{l}\text { Sodium bicarbonate with target bicarbonate } \\
\text { levels of } 24 \pm 1 \mathrm{mEq} / \mathrm{L}\end{array}$ \\
\hline Control & $\begin{array}{l}\text { No intervention, partial correction if } \\
\text { bicarbonate }<18 \mathrm{mEq} / \mathrm{L} \text { (up to } \\
22 \mathrm{mEq} / \mathrm{L} \text { ) }\end{array}$ & Placebo & $\begin{array}{l}\text { Rescue therapy of sodium bicarbonate with } \\
\text { target bicarbonate level of } 20 \pm 1 \mathrm{mEq} / \mathrm{L}\end{array}$ \\
\hline Locations & Multiple centers in Italy & $\begin{array}{l}2 \text { centers in the United States } \\
\text { (Bronx, NY and Cleveland, OH) }\end{array}$ & Single center in Vienna, Austria \\
\hline Follow up length & 36 months & 24 months & 24 months \\
\hline Primary outcome & Doubling of $\mathrm{Cr}$ & $\begin{array}{l}\text { HOMA-IR, sit to stand to sit speed, } \\
\text { DEXA of wrist, urinary NGAL \& KIM-1 }\end{array}$ & $\begin{array}{l}\text { Means of eGFR, calculated using the 4- } \\
\text { variable-MDRD Study equation }\end{array}$ \\
\hline $\begin{array}{l}\text { Secondary outcome } \\
\text { measures }\end{array}$ & All-cause death, start of dialysis & $\begin{array}{l}\text { Glucose disposal rate by euglycemic } \\
\text { hyperinsulinemic clamp, hand-grip } \\
\text { strength, serum calcium, phosphate, } \\
\text { 1,25-dihydroxyvitamin D, PTH, Cr, } \\
\text { cystatin C, urinary albumin/Cr ratio, } \\
\text { urinary cystatin }\end{array}$ & $\begin{array}{l}\text { Death, need for renal replacement therapy, } \\
\text { change in markers of bone metabolism }\end{array}$ \\
\hline
\end{tabular}

Abbreviations: CKD, chronic kidney disease; $\mathrm{Cr}$, creatinine; HOMA-IR, homeostasis model assessment-estimated insulin resistance; DEXA, dual energy X-ray absorptiometry; NGAL, urinary neutrophil gelatinase-associated lipocalin; KIM-1, kidney injury molecule-1; PTH, parathyroid hormone; eGFR, estimated glomerular filtrate rate; MDRD, modification of diet in renal disease; NY, New York; OH, Ohio.

$\wedge$ Our institution is one of the centers for the study (NCT01452412) and one of us (MKA) is a co-investigator. The information presented is updated from clinicaltrials.gov.

\#Recruitment was planned to start in October 2013.

Chronic metabolic acidosis is a common complication of CKD and appears to contribute to the progression of kidney disease. High dietary acid intake has also been demonstrated to worsen kidney function by induction of metabolic acidosis and/or subclinical acid retention. The factors that have been implicated in this effect of acidosis on CKD progression include ammonia-induced activation of the alternative complement system, as well as increased endothelin and aldosterone production. Existing evidence from clinical trials suggests that alkali therapy could retard the progression of CKD. Increased fruit and vegetable consumption appears to be a reasonable alternative to alkali therapy for patients with mild metabolic acidosis and without hyperkalemia. However, definitive evidence is lacking for optimal evidence-based practice guidelines. Ongoing trials will hopefully facilitate more evidencebased treatment of metabolic acidosis in the future.

\section{Competing interests}

The authors declare that they have no competing interest.

\section{Authors' contributions}

WC drafted the manuscript and both WC and MKA revised it and approved the final manuscript. Both authors have read and approved the final manuscript.

\section{Acknowledgements}

This research was supported by an American Society of Nephrology Carl W. Gottschalk Research Scholar Grant, National Institutes of Health (NIH) grant T32 DK007110, and by Clinical and Translational Science Award (CTSA) grants 1 UL1 TR001073-01, 1 TL1 TR001072-01, 1 KL2 TR001071-01 from the National Center for Advancing Translational Sciences (NCATS), a component of the $\mathrm{NIH}$. Its contents are solely the responsibility of the authors and do not necessarily represent the official views of the $\mathrm{NIH}$.

Received: 8 January 2014 Accepted: 31 March 2014

Published: 3 April 2014

\section{References}

1. Coresh J, Selvin E, Stevens LA, Manzi J, Kusek JW, Eggers P, Van Lente F, Levey AS: Prevalence of chronic kidney disease in the United States. JAMA 2007, 298(17):2038-2047.

2. Moranne O, Froissart M, Rossert J, Gauci C, Boffa JJ, Haymann JP, M'Rad MB, Jacquot C, Houillier P, Stengel B, Fouqueray B, the NephroTest Study Group: Timing of onset of CKD-related metabolic complications. J Am SoC Nephrol 2009, 20(1):164-171. 
3. Eustace JA, Astor B, Muntner PM, Ikizler TA, Coresh J: Prevalence of acidosis and inflammation and their association with low serum albumin in chronic kidney disease. Kidney Int 2004, 65(3):1031-1040.

4. Shah SN, Abramowitz M, Hostetter TH, Melamed ML: Serum bicarbonate levels and the progression of kidney disease: a cohort study. Am J Kidney Dis 2009, 54(2):270-277.

5. Kraut JA, Mishler DR, Singer FR, Goodman WG: The effects of metabolic acidosis on bone formation and bone resorption in the rat. Kidney Int 1986, 30(5):694-700.

6. Mak RH: Effect of metabolic acidosis on insulin action and secretion in uremia. Kidney Int 1998, 54(2):603-607.

7. Bailey JL, Wang X, England BK, Price SR, Ding X, Mitch WE: The acidosis of chronic renal failure activates muscle proteolysis in rats by augmenting transcription of genes encoding proteins of the ATP-dependent ubiquitin-proteasome pathway. J Clin Invest 1996, 97(6):1447-1453.

8. Ding H, Gao XL, Hirschberg R, Vadgama JV, Kopple JD: Impaired actions of insulin-like growth factor 1 on protein Synthesis and degradation in skeletal muscle of rats with chronic renal failure. Evidence for a postreceptor defect. J Clin Invest 1996, 97(4):1064-1075.

9. Ballmer PE, McNurlan MA, Hulter HN, Anderson SE, Garlick PJ, Krapf R: Chronic metabolic acidosis decreases albumin synthesis and induces negative nitrogen balance in humans. J Clin Invest 1995, 95(1):39-45.

10. Kovesdy CP, Anderson JE, Kalantar-Zadeh K: Association of serum bicarbonate levels with mortality in patients with non-dialysis-dependent CKD. Nephrol Dial Transplant 2009, 24(4):1232-1237.

11. Raphael KL, Wei G, Baird BC, Greene T, Beddhu S: Higher serum bicarbonate levels within the normal range are associated with better survival and renal outcomes in African Americans. Kidney Int 2011, 79(3):356-362

12. Menon V, Tighiouart H, Vaughn NS, Beck GJ, Kusek JW, Collins AJ, Greene T, Sarnak MJ: Serum bicarbonate and long-term outcomes in CKD. Am J Kidney Dis 2010, 56(5):907-914.

13. Navaneethan SD, Schold JD, Arrigain S, Jolly SE, Wehbe E, Raina R, Simon JF, Srinivas TR, Jain A, Schreiber MJ Jr, Nally JV Jr: Serum bicarbonate and mortality in stage 3 and stage 4 chronic kidney disease. Clin J Am SoC Nephrol 2011, 6(10):2395-2402.

14. Dobre M, Yang W, Chen J, Drawz P, Hamm LL, Horwitz E, Hostetter T, Jaar B, Lora CM, Nessel L, Ojo A, Scialla J, Steigerwalt S, Teal V, Wolf M, Rahman M: Association of serum bicarbonate with risk of renal and cardiovascular outcomes in CKD: a report from the Chronic Renal Insufficiency Cohort (CRIC) study. Am J Kidney Dis 2013, 62(4):670-678.

15. Kanda E, Ai M, Yoshida M, Kuriyama R, Shiigai T: High serum bicarbonate level within the normal range prevents the progression of chronic kidney disease in elderly chronic kidney disease patients. BMC Nephrol 2013, 14:4.

16. Raphael KL, Zhang Y, Wei G, Greene T, Cheung AK, Beddhu S, El Nahas M: Serum bicarbonate and mortality in adults in NHANES III. Nephrol Dial Transplant 2013, 28(5):1207-1213.

17. Rose BD, Post TW: Clinical Physiology of Acid-base and Electrolyte Disorders. Fifthth edition. USA: McGraw-Hill; 2000.

18. Van Slyke DD, Linder GC, Hiller A, Leiter L, Mclntosh JF: The Excretion of Ammonia and Titratable Acid in Nephritis. J Clin Invest 1926, 2(3):255-288.

19. Schwartz WB, Hall PW 3rd, Hays RM, Relman AS: On the mechanism of acidosis in chronic renal disease. J Clin Invest 1959, 38(1, Part 1):39-52.

20. Relman AS: Renal Acidosis and Renal Excretion of Acid in Health and Disease. Adv Intern Med 1964, 12:295-347.

21. Goodman AD, Lemann J Jr, Lennon EJ, Relman AS: Production, Excretion, and Net Balance of Fixed Acid in Patients with Renal Acidosis. J Clin Invest 1965, 44:495-506.

22. Litzow JR, Lemann J Jr, Lennon EJ: The effect of treatment of acidosis on calcium balance in patients with chronic azotemic renal disease. J Clin Invest 1967, 46(2):280-286.

23. Uribarri J, Douyon $\mathrm{H}$, Oh MS: A re-evaluation of the urinary parameters of acid production and excretion in patients with chronic renal acidosis. Kidney Int 1995, 47(2):624-627.

24. Gennari FJ: Metabolic acidosis in chronic renal insufficiency. In Acid-base disorders and their treatment. Edited by Gennari FJ, Adrogue HJ, Galla JH, Madias NE. Boca Raton: Taylor \& Francis; 2005:469-485.

25. Hakim RM, Lazarus JM: Biochemical parameters in chronic renal failure. Am J Kidney Dis 1988, 11(3):238-247.

26. Wallia R, Greenberg A, Piraino B, Mitro R, Puschett JB: Serum electrolyte patterns in end-stage renal disease. Am J Kidney Dis 1986, 8(2):98-104.
27. Widmer B, Gerhardt RE, Harrington JT, Cohen JJ: Serum electrolyte and acid base composition. The influence of graded degrees of chronic renal failure. Arch Intern Med 1979, 139(10):1099-1102

28. Abramowitz MK, Hostetter TH, Melamed ML: The serum anion gap is altered in early kidney disease and associates with mortality. Kidney Int 2012, 82(6):701-709.

29. Simpson DP: Control of hydrogen ion homeostasis and renal acidosis. Medicine 1971, 50(6):503-541.

30. Halperin ML, Ethier $\mathrm{JH}$, Kamel KS: Ammonium excretion in chronic metabolic acidosis: benefits and risks. Am J Kidney Dis 1989, 14(4):267-271.

31. Nath KA, Hostetter MK, Hostetter TH: Pathophysiology of chronic tubulointerstitial disease in rats. Interactions of dietary acid load, ammonia, and complement component C3. J Clin Invest 1985, 76(2):667-675.

32. Kohan DE, Inscho EW, Wesson D, Pollock DM: Physiology of endothelin and the kidney. Compr Physio/ 2011, 1(2):883-919.

33. Ruiz-Ortega M, Gomez-Garre D, Alcazar R, Palacios I, Bustos C, Gonzalez S, Plaza JJ, Gonzalez E, Egido J: Involvement of angiotensin II and endothelin in matrix protein production and renal sclerosis. J Hypertens Supp/ 1994, 12(4):S51-58.

34. Remuzzi G: Role of endothelin in the development of glomerulosclerosis. Kidney Blood Press Res 1996, 19(3-4):182-183.

35. Wesson DE: Endogenous endothelins mediate increased distal tubule acidification induced by dietary acid in rats. J Clin Invest 1997, 99(9):2203-2211.

36. Wesson DE, Nathan T, Rose T, Simoni J, Tran RM: Dietary protein induces endothelin-mediated kidney injury through enhanced intrinsic acid production. Kidney Int 2007, 71(3):210-217.

37. Phisitkul S, Hacker C, Simoni J, Tran RM, Wesson DE: Dietary protein causes a decline in the glomerular filtration rate of the remnant kidney mediated by metabolic acidosis and endothelin receptors. Kidney Int 2008, 73(2):192-199.

38. Ponda MP, Hostetter TH: Aldosterone antagonism in chronic kidney disease. Clin J Am Soc Nephrol 2006, 1(4):668-677.

39. Greene $\mathrm{EL}$, Kren S, Hostetter TH: Role of aldosterone in the remnant kidney model in the rat. J Clin Invest 1996, 98(4):1063-1068.

40. Aldigier JC, Kanjanbuch T, Ma $\sqcup$, Brown NJ, Fogo AB: Regression of existing glomerulosclerosis by inhibition of aldosterone. J Am Soc Nephrol 2005, 16(11):3306-3314.

41. Nishiyama A, Abe Y: Molecular mechanisms and therapeutic strategies of chronic renal injury: renoprotective effects of aldosterone blockade. J Pharmacol Sci 2006, 100(1):9-16.

42. Nishiyama A, Yao L, Nagai Y, Miyata K, Yoshizumi M, Kagami S, Kondo S, Kiyomoto H, Shokoji T, Kimura S, kohno M, Abe Y: Possible contributions of reactive oxygen species and mitogen-activated protein kinase to renal injury in aldosterone/salt-induced hypertensive rats. Hypertension 2004, 43(4):841-848

43. Schambelan M, Sebastian A, Katuna BA, Arteaga E: Adrenocortical hormone secretory response to chronic $\mathrm{NH} 4 \mathrm{Cl}$-induced metabolic acidosis. Am J Physiol 1987, 252(4 Pt 1):E454-460.

44. Khanna A, Simoni J, Wesson DE: Endothelin-induced increased aldosterone activity mediates augmented distal nephron acidification as a result of dietary protein. J Am Soc Nephrol 2005, 16(7):1929-1935.

45. Wesson DE, Simoni J: Acid retention during kidney failure induces endothelin and aldosterone production which lead to progressive GFR decline, a situation ameliorated by alkali diet. Kidney Int 2010, 78(11):1128-1135.

46. Raj S, Scott DR, Nguyen T, Sachs G, Kraut JA: Acid stress increases gene expression of proinflammatory cytokines in Madin-Darby canine kidney cells. Am J Physiol Ren Physiol 2013, 304(1):F41-48.

47. Scialla JJ, Anderson CA: Dietary acid load: a novel nutritional target in chronic kidney disease? Adv Chronic Kidney Dis 2013, 20(2):141-149.

48. Remer T: Influence of diet on acid-base balance. Semin Dial 2000, 13(4):221-226

49. Copeland SR: Potential hominin plant foods in northern Tanzania: semi-arid savannas versus savanna chimpanzee sites. J Hum Evol 2009, 57(4):365-378.

50. Konner M, Eaton SB: Paleolithic nutrition: twenty-five years later. Nutr Clin Pract 2010, 25(6):594-602.

51. Sebastian A, Frassetto LA, Sellmeyer DE, Merriam RL, Morris RC Jr: Estimation of the net acid load of the diet of ancestral preagricultural Homo sapiens and their hominid ancestors. Am J Clin Nutr 2002, 76(6):1308-1316. 
52. Strohle A, Hahn A, Sebastian A: Estimation of the diet-dependent net acid load in 229 worldwide historically studied hunter-gatherer societies. Am J Clin Nutr 2010, 91(2):406-412.

53. Eaton SB, Konner MJ, Cordain L: Diet-dependent acid load, Paleolithic [corrected] nutrition, and evolutionary health promotion. Am J Clin Nutr 2010, 91(2):295-297.

54. Smith E, Morowitz HJ: Universality in intermediary metabolism. Proc Natl Acad Sci U S A 2004, 101(36):13168-13173.

55. Eaton SB, Konner M: Paleolithic nutrition. A consideration of its nature and current implications. N Engl J Med 1985, 312(5):283-289.

56. Cordain L, Eaton SB, Sebastian A, Mann N, Lindeberg S, Watkins BA, O'Keefe $\mathrm{JH}$, Brand-Miller J: Origins and evolution of the Western diet: health implications for the 21st century. Am J Clin Nutr 2005, 81 (2):341-354.

57. Wesson DE: Dietary acid increases blood and renal cortical acid content in rats. Am J Physiol 1998, 274(1 Pt 2):F97-103.

58. Wesson DE, Simoni J: Increased tissue acid mediates a progressive decline in the glomerular filtration rate of animals with reduced nephron mass. Kidney Int 2009, 75(9):929-935.

59. Wesson DE, Simoni J, Broglio K, Sheather S: Acid retention accompanies reduced GFR in humans and increases plasma levels of endothelin and aldosterone. Am J Physiol Ren physiol 2011, 300(4):F830-837.

60. Amodu A, Abramowitz MK: Dietary Acid, Age, and Serum Bicarbonate Levels among Adults in the United States. Clin J Am Soc Nephrol 2013, 8(12):2034-2042.

61. Scialla JJ, Appel LJ, Astor BC, Miller ER 3rd, Beddhu S, Woodward M, Parekh RS, Anderson CA: Estimated net endogenous acid production and serum bicarbonate in African Americans with chronic kidney disease. Clin J Am Soc Nephrol 2011, 6(7):1526-1532.

62. Scialla JJ, Appel LJ, Astor BC, Miller ER 3rd, Beddhu S, Woodward M, Parekh RS, Anderson CA, African American Study of Kidney D, Hypertension Study $G$ : Net endogenous acid production is associated with a faster decline in GFR in African Americans. Kidney Int 2012, 82(1):106-112.

63. de Brito-Ashurst I, Varagunam M, Raftery MJ, Yaqoob MM: Bicarbonate supplementation slows progression of CKD and improves nutritional status. J Am Soc Nephrol 2009, 20(9):2075-2084.

64. Phisitkul S, Khanna A, Simoni J, Broglio K, Sheather S, Rajab MH, Wesson DE: Amelioration of metabolic acidosis in patients with low GFR reduced kidney endothelin production and kidney injury, and better preserved GFR. Kidney Int 2010, 77(7):617-623.

65. Mahajan A, Simoni J, Sheather SJ, Broglio KR, Rajab MH, Wesson DE: Daily oral sodium bicarbonate preserves glomerular filtration rate by slowing its decline in early hypertensive nephropathy. Kidney Int 2010, 78(3):303-309.

66. Goraya N, Simoni J, Jo C, Wesson DE: Dietary acid reduction with fruits and vegetables or bicarbonate attenuates kidney injury in patients with a moderately reduced glomerular filtration rate due to hypertensive nephropathy. Kidney Int 2012, 81(1):86-93.

67. Goraya N, Simoni J, Jo CH, Wesson DE: A comparison of treating metabolic acidosis in CKD stage 4 hypertensive kidney disease with fruits and vegetables or sodium bicarbonate. Clin J Am Soc Nephrol 2013, 8(3):371-381.

68. Susantitaphong P, Sewaralthahab K, Balk EM, Jaber BL, Madias NE: Short- and long-term effects of alkali therapy in chronic kidney disease: a systematic review. Am J Nephrol 2012, 35(6):540-547.

69. Correction of Metabolic Acidosis in End Stage Renal Disease. [clinicaltrials.gov/show/NCT01640119].

70. Akali Therapy in Chronic Kidney Disease. [clinicaltrials.gov/show/NCT01452412].

71. Gaggl M, Cejka D, Plischke M, Heinze G, Fraunschiel M, Schmidt A, Horl WH, Sunder-Plassmann G: Effect of oral sodium bicarbonate supplementation on progression of chronic kidney disease in patients with chronic metabolic acidosis: study protocol for a randomized controlled trial (SoBic-Study). Trials 2013, 14(1):196.

doi:10.1186/1471-2369-15-55

Cite this article as: Chen and Abramowitz: Metabolic acidosis and the progression of chronic kidney disease. BMC Nephrology 2014 15:55.

\section{Submit your next manuscript to BioMed Central and take full advantage of:}

- Convenient online submission

- Thorough peer review

- No space constraints or color figure charges

- Immediate publication on acceptance

- Inclusion in PubMed, CAS, Scopus and Google Scholar

- Research which is freely available for redistribution

Submit your manuscript at www.biomedcentral.com/submit 